\title{
Trends in overall mortality and from diseases of the circulatory system in elderly individuals in Rio Branco, Acre, 1980-2012
}

Polyana Caroline de Lima Bezerra1,2 Gina Torres Rego Monteiro ${ }^{3}$

\section{Abstract}

Objective: To analyze trends in general mortality and circulatory system disease mortality among elderly persons living in the city of Rio Branco, Acre, Brazil, from 1980 to 2012. Method: A study of the cause of death of elderly people was carried out from the data available in the Brazilian Mortality Information System. Crude and age-based overall and circulatory system mortality rates were calculated. The trend analyses of these rates were performed using the JoinPoint Regression program. Results: Despite the reductions in mortality rates, diseases of the circulatory system remained the main cause of death of the elderly in Rio Branco. The decrease in overall mortality rates was higher among elderly women and those aged 70 years or older. There was a tendency for death rates due to diseases of the circulatory system to decline among elderly men and grow among elderly women. Conclusion: The mortality rate among the elderly in Rio Branco revealed a declining trend. Deaths from diseases of the circulatory system were the leading cause of death, suggesting that research should be carried out to assess the need for investment to ensure that increased longevity is accompanied by good quality of life.

\footnotetext{
Universidade Federal do Acre, Centro de Ciências da Saúde e do Desporto. Rio Branco, Acre, Brasil.

2 Fundação Oswaldo Cruz, Escola Nacional de Saúde Pública Sérgio Arouca, Programa de Doutorado em Saúde Pública e Meio Ambiente. Rio de Janeiro, Rio de Janeiro, Brasil.

3 Fundação Oswaldo Cruz, Escola Nacional de Saúde Pública Sérgio Arouca, Departamento de Epidemiologia e Métodos Quantitativos em Saúde. Rio de Janeiro, Rio de Janeiro, Brasil.
}

Keywords: Mortality. Health of the Elderly. Epidemiology. Cardiovascular System Longevity. 


\section{INTRODUCTION}

Until the late 1970s the demographic profile of Brazil was characterized by a predominantly young population, the result of a lengthy period of high fertility. However, changes have occurred to this profile in recent years. One of the clearest signs of this is the narrowing of the base of the population pyramid over time, with significant reductions in the number of children and young people in the total population ${ }^{1}$. This change has also been observed in Rio Branco, where the proportion of under 20s declined from $55.2 \%$ (1980 Census) to $39.3 \%$ (2010 Census), while those over 60 increased from $4.2 \%$ to $6.4 \%$ in the same surveys 2 .

In population aging it is important to understand the inequalities in mortality among the elderly through studies that consider the epidemiological, demographic and social aspects relevant to this population. Mortality information is one of the main health indicators of a population. Mortality rates and numbers, locations, ages, and major causes of death are crucial to policy debates, planning, interventions, establishing research priorities and developing new technologies. An analysis of trends in causes of death provides an important geographical summary of whether society and public policy is effective in reducing mortality, especially through preventable causes, and where more investment is required. Thus, it can be said that mortality statistics are highly useful ${ }^{3,4}$.

In this context, the present article aims to analyze trends in overall mortality and mortality from circulatory diseases in elderly persons living in the municipal region of Rio Branco, Acre, from 1980 to 2012.

\section{METHOD}

An ecological study of the mortality data of people aged 60 years and over in Rio Branco, the capital of the state of Acre in the Western Amazon region of Brazil, was performed. According to the 2010 census of the Brazilian Institute of Geography and Statistics (IBGE) 5 , the population of Rio Branco was composed of 336,038 inhabitants, 21,577 of whom were over 60 years of age, with a higher proportion of females $(53.6 \%)$.
Data from the Mortality Information System $(\mathrm{MIS})^{6}$, which consolidates all Brazilian deaths, were used. Deaths were coded according to the $9^{\text {th }}$ revision of the International Classification of Diseases (ICD) for the years 1980 to 1995 , and the $10^{\text {th }}$ revision for the years 1996 to 2012 .

The absolute and relative frequencies of the following variables were analyzed: gender, age group (60 to 69 years, 70 to 79 years and 80 years or more); ethnicity/color (white, brown, black, yellow/AsianBrazilian or indigenous); marital status (married, single, widowed, separated or other); schooling (zero, 1 to 8 years, 9 to 10 years and 11 years or more of study); place of death (hospital, home, public highway or other); cause of death, and year of death (from 1980 to 2012).

The proportionate mortality by chapter, excluding deaths from ill-defined causes, was calculated from the death data of the elderly (Chapters XVI in ICD-9 and XVIII in ICD-10). The proportion of deaths from the six most frequent episodes in the previous year was compared for 1980, 1996 and 2012.

The crude mortality rate per hundred thousand inhabitants was calculated (ratio between the number of deaths of people aged 60 years and over and the population living in Rio Branco in this age group in the relevant year) along with the specific rates by age group and gender. Age-standardized rates using the direct method were also calculated, using as standard a theoretical world population ${ }^{7}$, with the objective of controlling the influence of population aging on the mortality trends.

Analysis of the trend of the mortality rates from circulatory system diseases was also carried out, as this chapter has the highest number of deaths over the entire period. To improve the quality of the data, we used the $50 \%$ proportional redistribution adjustment method for deaths with an ill-defined basic cause (codes 780-799 of ICD-9 and R00-R99 of ICD-10), as this correction factor is recommended by the World Health Organization (WHO) ${ }^{8}$ for calculations of mortality and has been previously used in Brazil by França et al. . This redistribution maintained the proportion of deaths specified (i.e. by category) in the chapter on diseases of the circulatory system. 
Trend analyzes were carried out by calculating the annual percentage change in mortality rates for the elderly for the set of deaths and for the chapter of diseases of the circulatory system using the JoinPoint Regression statistical program (http://surveillance. cancer.gov/joinpoint/). The JoinPoint technique uses log-transformed rates to identify inflection points throughout the period which can describe significant changes in trends through the Annual Percentage Change, which allows the scale of the change of a rate in a given period of time to be determined $^{10}$. In this system, the inflection points correspond to k-1 segments. Statistical significance tests for choosing the best model were based on the Monte Carlo permutation method, considering a value of $p<0.05$.

\section{RESULTS}

During the study period (1980 to 2012) there were 44,007 deaths of people aged 60 years of age or older residing in Rio Branco, Acre, of which $62.3 \%$ involved men. Among this age group, 35.6\% were aged 70 to 79 years and $34.8 \%$ were aged 80 years or more. A predominance of brown-skinned individuals, single people, with low schooling and who died in hospital was observed (Table 1).

Table 1. Characterization of deaths of people aged 60 years or mode between 1980 and 2012. Rio Branco, Acre.

\begin{tabular}{|c|c|}
\hline Variables* & $\mathrm{n}(\%)$ \\
\hline \multicolumn{2}{|l|}{ Gender } \\
\hline Male & $27,368(62.3)$ \\
\hline Female & $16,579(37.7)$ \\
\hline \multicolumn{2}{|l|}{ Age group (years) } \\
\hline $60-69$ & $5,249(29.7)$ \\
\hline $70-79$ & $6,287(35.6)$ \\
\hline 80 and over & $6,144(34.8)$ \\
\hline \multicolumn{2}{|l|}{ Ethnicity/color ** } \\
\hline White & $4,564(29.6)$ \\
\hline Black & $823(5.3)$ \\
\hline Brown & $9,739(63.1)$ \\
\hline Yellow/Asian Brazilian & $203(1.3)$ \\
\hline Indigenous & $94(0.6)$ \\
\hline \multicolumn{2}{|l|}{ Marital status } \\
\hline Married & $11,433(30.5)$ \\
\hline Not married & $19,082(50.8)$ \\
\hline Widower & $5,938(15.8)$ \\
\hline Separated & $640(1.7)$ \\
\hline Others & $446(1.2)$ \\
\hline \multicolumn{2}{|l|}{ Schooling (years of study) } \\
\hline 0 & $10,801(58.4)$ \\
\hline 1 to 8 & $5,675(30.7)$ \\
\hline 9 to 10 & $1,038(5.6)$ \\
\hline 11 or more & $643(3.5)$ \\
\hline \multicolumn{2}{|l|}{ Place of death } \\
\hline Hospital & $28,919(66.8)$ \\
\hline Home & $11,171(25.8)$ \\
\hline Public highway & $1,951(4.5)$ \\
\hline Others & $1,238(2.9)$ \\
\hline Total deaths & 44,007 \\
\hline
\end{tabular}

Source: Mortality Information System (MIS). *The differences in absolute values, in all variables, correspond to the data overlooked in the MIS/DATASUS; **Data from 1996 to 2012, as data from previous years are not available in MIS/DATASUS. 
The distribution of deaths by ICD chapter, excluding ill-defined causes, revealed deaths from the circulatory disease chapter as the most frequent in elderly residents in Rio Branco during the studied period. Deaths in this chapter accounted for more than half of those recorded in 1980 (50.6\%) and practically one third of those recorded in 2012 (31.2\%). There was a change in the percentage of deaths due to diseases of the respiratory system, which were the second most prevalent in 2012, increasing from $11.7 \%$ of deaths in 1980 to $19.7 \%$. There was an increase in the percentage of deaths in the endocrine, nutritional and metabolic diseases chapter (from $0.6 \%$ to $10.7 \%$ ) and from external causes (from 3.2\% to 4.6\%). A different pattern was observed in the chapter on parasitic and infectious diseases, which showed an increase followed by a reduction: from $6.5 \%$ (1980) to $10.3 \%$ (in 1996) and $4.5 \%$ of elderly deaths in 2012 (Table 2).

Age-standardized mortality rates oscillated over the period and were always higher among men. For all deaths, the lowest rate was 3,497.49 deaths/100,000 elderly in 1990, and the highest, 5,203.00 deaths/100,000 elderly people in 1995 (Figure 1). The mortality rates by age were higher for more advanced ages in all the years analyzed, exhibiting significant variation in those older than 80 years (Figure 1).

There were 5,789 deaths caused by circulatory system diseases (CSD) in the period studied. The redistribution adjustment methodology used included another 2,442 deaths previously recorded in the chapter on ill-defined causes. Figure 2 shows the behavior of the standardized mortality rates before and after this redistribution, for men, women and both genders. It should be noted that the redistribution was greater at the beginning of the series, becoming less significant from 2006. There was an increasing trend in the overall rate, reflecting the growth in female deaths, while there was a decline in male rates during the period.

Table 2. Proportional distribution of deaths among elderly persons in 1980, 1996 and 2012. Rio Branco, Acre.

\begin{tabular}{llll}
\hline Chapter of deaths* & 1980 & 1996 & 2012 \\
\cline { 2 - 4 } & $\mathrm{n}(\%)$ & $\mathrm{n}(\%)$ & $\mathrm{n}(\%)$ \\
\hline Chapter I - Infectious and parasitic diseases & $10(6.5)$ & $37(10.3)$ & $38(4.5)$ \\
Chapter II - Neoplasms (tumors) & $30(19.5)$ & $46(12.8)$ & $157(18.5)$ \\
Chapter IV - Nutritional and Metabolic Endocrine Diseases & $1(0.6)$ & $31(8.7)$ & $91(10.7)$ \\
Chapter IX - Diseases of the circulatory system & $78(50.6)$ & $143(39.9)$ & $264(31.2)$ \\
Chapter X - Diseases of the respiratory system & $18(11.7)$ & $55(15.4)$ & $167(19.7)$ \\
Chapter XX - External causes of morbidity and mortality & $5(3.2)$ & $13(3.6)$ & $39(4.6)$ \\
Other chapters & $12(7.8)$ & $12(9.3)$ & $67(10.8)$ \\
Total & $154(100)$ & $358(100)$ & $847(100)$ \\
\hline
\end{tabular}

Source: Mortality Information System (MIS). *Except ill-defined causes. International Classification of Disease (ICD - 9 and ICD-10). 


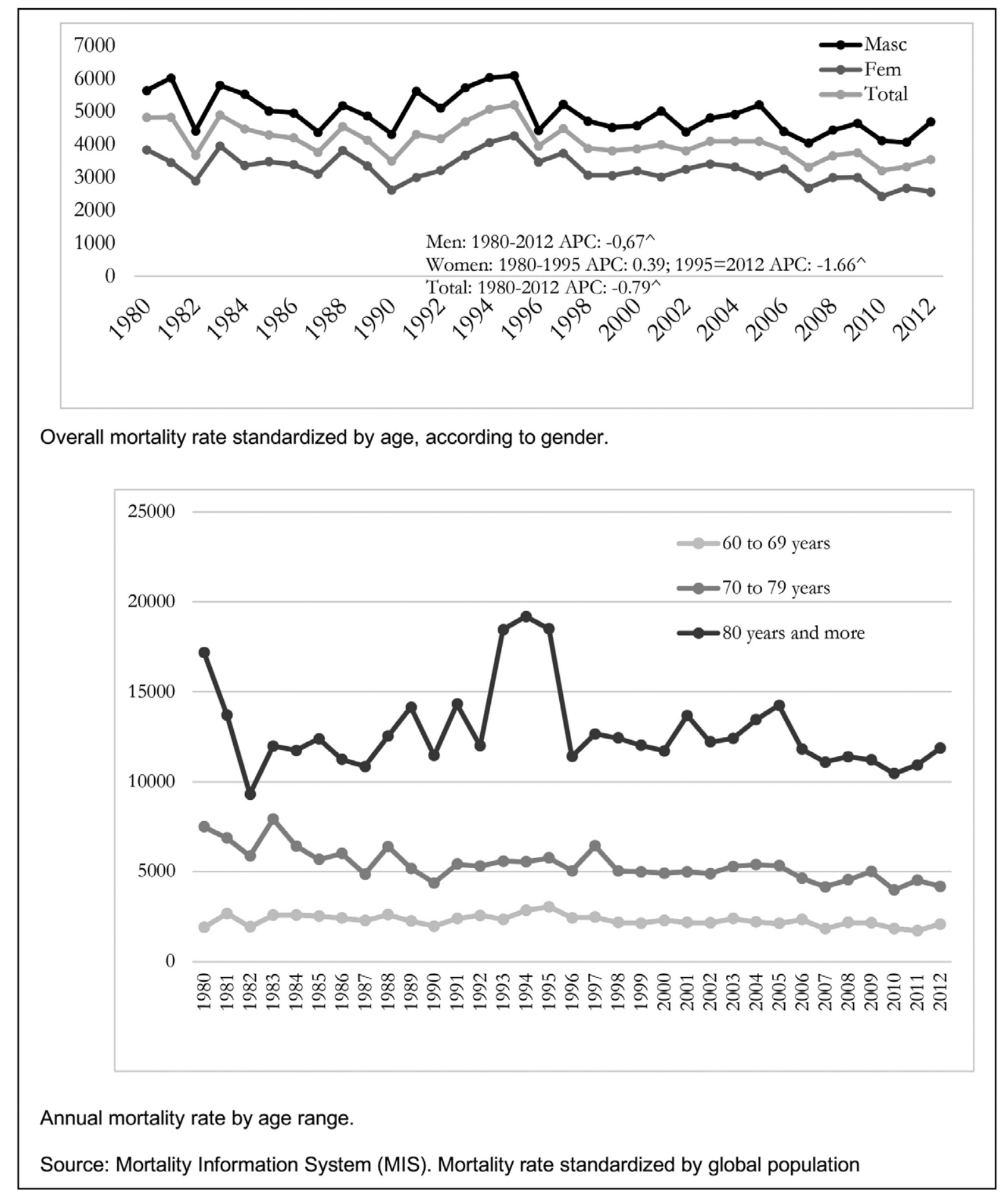

Figure 1. Mortality rate among elderly persons from 1980 to 2012. Rio Branco, Acre. 

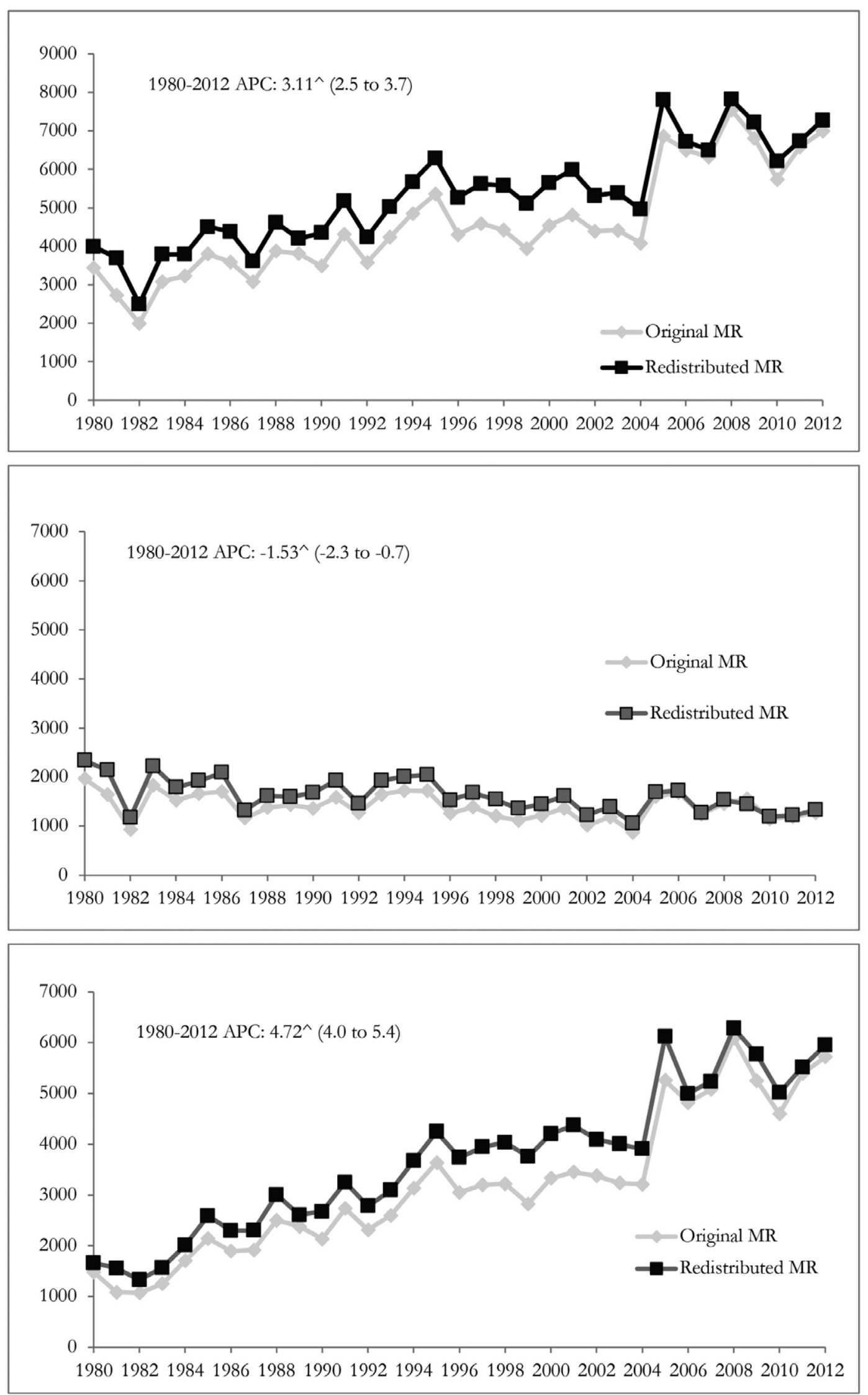

Source: Mortality Information System (MIS). APC $=$ annual percentage change ^ ${ }^{\wedge}$-value $<0.05$; Mortality rate standardized by global population.

Figure 2. Mortality rates standardized by disease of the circulatory system, original and redistributed from deaths due to ill-defined causes, both genders. Rio Branco, Acre, 1980-2012. 
The overall age-specific mortality rate over the whole period was higher among elderly persons aged 80 or over, with a significant increase from 2005. In Rio Branco, the mortality among the elderly group exhibited a declining trend in all age groups, in both genders, except for women in the age group of 80 years and over, between 1982 and
1988. The APC for both genders in this range was an increase of $3.5 \%$ per year from 1982 to 1993 , with statistical significance, in comparison with a more significant variation in women in the same range from 1982 to 1988 (APC=12.2\% pa), followed by a small reduction $(-0.7 \% \mathrm{pa})$ in subsequent years (Table 3).

Table 3. Annual percentage variation (APC) of general mortality rates and circulatory diseases in the elderly according to sex and age group. Rio Branco, Acre, 1980-2012.

\begin{tabular}{|c|c|c|c|c|c|c|}
\hline \multirow{2}{*}{$\begin{array}{l}\text { Gender } \\
\text { Age range }\end{array}$} & \multicolumn{2}{|l|}{ 1st Trend } & \multicolumn{2}{|l|}{ 2nd Trend } & \multicolumn{2}{|l|}{ 3rd Trend } \\
\hline & Period & $\operatorname{APC}\left(\mathrm{CI}_{95 \%}\right)$ & Period & $\operatorname{APC}\left(\mathrm{CI}_{95 \%}\right)$ & Period & $\operatorname{APC}\left(\mathrm{CI}_{95 \%}\right)$ \\
\hline \multicolumn{7}{|c|}{ Overall mortality } \\
\hline \multicolumn{7}{|c|}{ Men } \\
\hline 60 to 69 & $1980-2012$ & $-0,6(-1,0 ;-0,1)$ & & & & \\
\hline 70 to 79 & $1980-2012$ & $-0,7(-0,3 ;-3,2)$ & & & & \\
\hline 80 and over & $1980-1993$ & $-1,4(-1,1 ; 4,0)^{a}$ & $1993-2012$ & $-1,9(-3,2 ;-0,4)$ & & \\
\hline \multicolumn{7}{|l|}{ Women } \\
\hline 60 to 69 & $1980-1995$ & $2,2(0,3 ; 4,2)$ & $1995-2012$ & $-2,0(-3,5 ;-0,5)$ & & \\
\hline 70 to 79 & $1980-2012$ & $-1,8(-2,4 ;-1,3)$ & & & & \\
\hline 80 and over & 1980-1982 & $-43,6(-64,7 ;-9,9)$ & $1982-1988$ & $12,2(1,0 ; 24,5)$ & $1988-2012$ & $-0,7(-1,7 ;-0,3)^{a}$ \\
\hline \multicolumn{7}{|l|}{ Both } \\
\hline 60 to 69 & $1980-2012$ & $-0.6(-6.0 ;-1.0)$ & & & & \\
\hline 70 to 79 & $1980-2012$ & $-1.3(-1.7 ;-0.9)$ & & & & \\
\hline 80 and over & $1980-1982$ & $-23.0(-45.4 ; 8.6)^{a}$ & $1982-1993$ & $3.5(0.7 ; 6.3)$ & 1993-2012 & $-1.6(-2.7 ;-0.7)$ \\
\hline \multicolumn{7}{|c|}{$\begin{array}{l}\text { Mortality from diseases of the } \\
\text { circulatory system }\end{array}$} \\
\hline \multicolumn{7}{|c|}{ Men } \\
\hline 60 to 69 & $1980-2012$ & $-0.89(-1.7 ;-0.1)$ & & & & \\
\hline 70 to 79 & $1980-1982$ & $-24.74(-50.9 ; 15.3)^{a}$ & 1982-2012 & $-1.05(-1.9 ;-0.2)$ & & \\
\hline 80 and over & 1980-1992 & $-1.62(-2.7 ;-0.5)$ & & & & \\
\hline \multicolumn{7}{|l|}{ Women } \\
\hline 60 to 69 & $1980-1983$ & $2.70(1.7 ; 3.7)$ & & & & \\
\hline 70 to 79 & $1980-2012$ & $2.37(1.5 ; 3.2)$ & & & & \\
\hline 80 and over & 1980-1996 & $5.32(4.4 ; 6.3)$ & & & & \\
\hline \multicolumn{7}{|l|}{ Both } \\
\hline 60 to 69 & $1980-1983$ & $1.29(0.6 ; 2.0)$ & & & & \\
\hline 70 to 79 & 1980-1996 & $1.03(0.4 ; 1.7)$ & & & & \\
\hline 80 and over & $1980-2012$ & $3.86(3.1 ; 4.6)$ & & & & \\
\hline
\end{tabular}


Table 3 also shows the predominance of a decline in mortality rates caused by CSD in men and women over the entire period. Analysis by age group revealed a difference in behavior, although overall there was an increasing trend, especially in the last age stratum (APC of 3.86; $\mathrm{CI}_{95 \%} 3.1$ to 4.6), despite the discrepancy in magnitude between the genders and age groups. The percentage of mortality due to CSD among elderly men aged 80 years or more declined by 1.62 per year from 1980 to 2012, while among elderly women there was an annual increase of 5.32 in the same period, both with statistical significance.

The most frequent specific causes in 2012 were: stroke ( $\mathrm{n}=48,18.2 \%$ ), acute myocardial infarction (AMI) $(n=43 ; 16.3 \%)$, sequelae of cerebrovascular disease $(n=32,12.1 \%)$, heart failure $(n=17,6.4 \%)$ and hypertensive heart disease $(n=16,6.1 \%)$. In all the specific causes of CSD, the highest number of deaths in both genders occurred in the age group of 80 years and over, with the exception of stroke deaths in men, which were higher in the 70-79 age group, and by AMI in the same age stratum, for both genders (male: $\mathrm{n}=11,36.7 \%$, female: $\mathrm{n}=5,38.5 \%$ ).

\section{DISCUSSION}

The mortality rate of the elderly in Rio Branco was greatest in males in every year analyzed and among those aged 80 years old or older. However, there was a declining trend in overall mortality for both genders. The chapter with the highest number of deaths was CSD, with an increasing trend over this period, in a pronounced manner for women, especially those aged 80 or over.

In recent decades in Brazil the age distribution of mortality exhibited a significant change, with a decline in infant deaths and an increase in the elderly proportion from 38\% in 1980 to $60 \%$ in 2007. However, even with increased longevity there is still a lack of information on how and from what people die of at more advanced ages, according to Mathias et al. ${ }^{11}$.

The greater proportion of male deaths in the overall mortality rates found in the present study were also observed in Recife (Pernambuco) ${ }^{12}$, where higher rates were found in elderly men (mean 5.44 deaths/100,000 inhabitants) than in elderly women (mean of 3.73 deaths/100,000 inhabitants) between the years 1996 to 2007. The paradoxical phenomenon of male and female survival observed in modern human societies, in which women experience greater longevity than men, results from both biological and environmental differences that include behavioral, cultural, and social factors ${ }^{13-15}$.

Several studies have considered both greater longevity and better quality of life in aging, with the prolongation of telomeres - a structure consisting of repeated filaments of proteins and DNA that make up the ends of the chromosomes ${ }^{13,15}$. The genetic advantages of women can be attributed to the difference in the reverse transcription of human telomeres (hTERT) that can be stimulated by the female hormone estrogen. This results in an increase in telomerase and longer telomeres, and consequently greater longevity than in men ${ }^{15}$. Another genetic advantage can be attributed to the $\mathrm{X}$ chromosome, which contains DNA repair genes. As women have two, they have an advantage over men (XY) in the event that the $\mathrm{X}$ chromosome is damaged ${ }^{14-17}$. Moreover, studies have demonstrated the advantages of genetic variants associated with longevity for both greater numbers of children and maternity at an advanced age (over 33 years of age). In this way, the survival of women can be an evolutionary mechanism or selective pressure through the choice of genetic variants that facilitate survival for a longer time, even after the age in which reproduction ceases ${ }^{16,17}$.

It is therefore important to point out that there are biological aspects that can determine the trend of greater longevity in women, and that it is not merely a demographic phenomenon. In addition, it is known that women use health services more, enabling earlier diagnosis and treatment, which may result in lower mortality ${ }^{18}$.

The annual percentage changes in overall mortality in the years studied in Rio Branco were more significant in women aged 80 years and over, with a decrease of $43.6 \%$ between 1980 and 1982, followed by those from 60 to 69 years (APC of -2.0). In men, the most significant variation was also in the age group of older than 79 years $($ APC $=-1.9)$ as of 1993. This pattern of expressive declines in mortality rates in the elderly was also found in studies in the northeast and in the southeast of Brazill ${ }^{12,19,20}$. 
The distribution of causes of death in Rio Branco corroborates the profile described by Miranda et al. ${ }^{21}$, which indicated a predominance in Brazil between 1998 to 2013 of diseases of the circulatory system, neoplasms and those of the respiratory system, with an increase in deaths due to endocrine diseases. In the present study a decline in mortality from CSD over time was observed. A study conducted in Rio Grande do Norte between 2001 and 2011 found that CSD were the main cause of death in the age groups of 60-69 years (32.8\%) and 80 years or older (35.3\%). The second most important chapter was that of neoplasms (22.9\%) among elderly persons from 60 to 69 years and those aged 80 or older $(10.0 \%)$. Diseases of the digestive tract and external causes represented significant percentages of proportional mortality among younger elderly persons, whereas ill-defined and respiratory diseases were more significant among the longest-lived ${ }^{19}$.

Similar to the mortality of the elderly in Rio Branco, a study carried out in the state of Mato Grosso with data from 1986 to 2006 found higher rates of mortality due to CSD in men and in older individuals. On the other hand, it found that, for almost all elderly age groups, deaths due to CSD declined by approximately $10 \%$ for both genders ${ }^{22}$.

Similar results were found in other Brazilian studies on mortality in the elderly caused by various diseases of the circulatory system ${ }^{23-26}$.

Garritano et al. ${ }^{24}$, when discussing the reduction in mortality rates due to strokes, indicated that this decline is related to the incidence and lethality of the disease, and that this explanation may extend to other CSD as they have similar risk factors and pathological mechanisms. The incidence is linked to risk factors such as hypertension, diabetes, obesity, smoking, low human development index (HDI), among others, while the lethality depends on the effectiveness of the treatment instituted.

Brazil is a large country, with significant inequality between regions and scarce resources allocated to public health. As a result, the most recommended procedures are not always available for the population in various localities ${ }^{24}$. For Mansur and Favarato, ${ }^{27}$ the progressive reduction in mortality in Brazil due to cardiovascular disease is more related to improvements in the quality of life of the population from birth than access to high technology services and procedures, which should be restricted to highrisk cases, where they are more effective. Although these aspects were not the object of the present study, they are believed to be related to the reduction of the mortality rate due to CSD in Rio Branco. It is therefore necessary to carry out other studies to verify such findings.

A study with data from 26 European Union countries ${ }^{28}$ from 1980 to 2009 found that, to a greater or lesser extent, there was a reduction in the mortality rate due to coronary disease in most countries and in all age groups, across both genders. However, recent increases have been observed in younger age groups in a small number of countries. The authors drew attention to the prevalence or permanence of important risk factors such as: smoking, obesity and diabetes at relatively high levels by European standards.

However, there was a reduction in mortality among the longest-lived, which may be the result of mortality from delayed, rather than avoided, coronary disease, with the reduction in mortality in the 65-74 age group, for example, partially offset by a lower reduction among older people. The mean APC for the full range of years in individuals aged 65 years and over was $22.3 \%$ among men and $22.2 \%$ among women ${ }^{28}$.

Declining trends in overall mortality and deaths from CSD were found among the elderly in Rio Branco in the present study, although there were differences in the period, in age groups and in genders. This type of finding raises important implications for public policies.

In Brazil, the challenges for health are well-known due to the failings of the Unified Health System (SUS), as alerted to by Oliveira et al. ${ }^{19}$, which has not achieved full universal coverage and still presents geographical gaps in the provision of health services of medium and high complexity and is not prepared to deal with the morbidities that will become more prevalent with the increase of the elderly population.

According to the National Health Survey $(\mathrm{PNS})^{18}, 45 \%$ of the Brazilian population has chronic noncommunicable diseases (CNCD) and use twice as many health services as those who 
do not have such illnesses. In another population survey ${ }^{29}$ conducted in Rio Branco in 2007, 11.9\% of the sample was composed of elderly people, and $76.7 \%$ of the participants reported having at least one of the 18 morbidities investigated. The most frequently reported diseases were spine $(30.8 \%)$, arterial hypertension (28.3\%) and depression (19.0\%).

The increase in the proportion of the elderly can generate a significant increase of the costs of hospitalizations of SUS. A study comparing hospitalization data from 2000 and 2010 reports that this increase stems from the most prevalent group of diseases in this age group, such as circulatory diseases and neoplasms, which were responsible for explaining, respectively, $110 \%$ and $31.4 \%$ of the increase in total hospitalization costs in Brazil in this period ${ }^{30}$. This scenario highlights the scale of investment needed to address diseases of advanced ages and the gaps in care, protection, healthy aging and integration of the elderly into society. The area of health must restructure funding sources and management processes to adequately address the issues associated with greater population longevity and overall system operation ${ }^{19}$.

However, it should be noted that the overall aging process itself, as evidenced by aggregate analysis data, with a trend of declining rates over the years, is also the result of improvements in public health policies, with a greater focus on the expansion of primary health care, especially since the 1994 implementation of the Family Health Program, as well as the creation of the National Primary Care Policy, the National Health Promotion Policy, the National Health Policy for the Elderly, and others. Borim et al. ${ }^{31}$, when analyzing the factors associated with the mortality of the elderly in Campinas, São Paulo, between 2008 and 2009, reinforced that strategies based on specific primary and secondary care directed at priority groups can have a positive impact on the reduction of mortality among the elderly.

In Rio Branco, the Municipal Policy on the Rights of the Elderly was only created in 2008 . However, the activities of the control and treatment of chronic noncommunicable diseases, such as arterial hypertension and diabetes, were the first to be implemented in the municipality, along with the Family Health Strategy, in the 1990s. These actions may explain some of the data on the reduction of death by CSD, as well as the overall mortality reduction data, together with the creation of the Hospital for the Elderly in 2004, as a reference for the specialized care and expansion of the health care network of the elderly (http:// noticias.terra.com.br/brasil/noticias/0,,OI289961EI1194,00-Lula+inaugura+hospital+para+idosos +no+Norte.html).

It is therefore important that population projections adopt strategies that consider the reduction of mortality among the elderly, and that health and social security policies are adopted that guarantee adequate living conditions for this part of the population, which presents a characteristic of growth and expectation of greater survival.

The results found should be analyzed with the care inherent to ecological studies. One limitation cited in studies using data based on death reports is the accuracy of mortality statistics. However, it is noteworthy that the data of the present study are the official data of the Ministry of Health and that several studies have been carried out evidencing the quality, functionality and coverage ${ }^{31-33}$ of the MIS. Specifically in relation to Acre, data on the causes of death were classified as satisfactory by a study that evaluated the mortality statistics of Brazilian states in the year $2000^{32}$. In 2011, the coverage of the MIS in Acre was $90.0 \%$, slightly lower than the rate for Brazil $(96.1 \%)^{33}$.

On the other hand, a strength of the present study is the zeal of the authors in performing the proportional redistribution of the ill-defined causes of death into the CSD chapter to carry out the analysis of mortality trends, according to the methodological proposal recommended by the $\mathrm{WHO}^{8}$. Moreover, the MIS is an important data source that can contribute to the epidemiological profile of a population. The evaluation of the level of health can be made by indicators that use, for the most part, the mortality data of a population to indirectly assess the health of a community ${ }^{34}$.

\section{CONCLUSION}

In summary, mortality from circulatory system diseases (CSD) remained the main cause of death among the elderly in Rio Branco between 1980 and 2012, and the mortality rate among men was greater 
than that among women for all age groups. It was also concluded that, in the capital of Acre, one of the component states of the Western Amazon, the general mortality trends of the elderly population show a declining trend over time.

It is suggested that other studies are carried out, based on the information generated by this article, to identify the origins of the declining mortality rate

\section{REFERENCES}

1. Wong LM, Carvalho JAM, Perpétuo IHO. A estrutura etária da população brasileira no curto e médio prazo: evidências sobre o panorama demográfico com referências às políticas sociais, particularmente as de saúde. In: Interagencial de Informações para Saúde. Demografia e saúde: contribuição para análise de situação e tendências. Brasília, DF: Organização Pan-Americana de Saúde; 2009. p. 37-63.

2. Instituto Brasileiro de Geografia e Estatístico, Ministério do Planejamento, Orçamento e Gestão. Cidades@[Internet]. Rio de Janeiro: IBGE; 2007 [acesso em 22 dez. 2017]. Disponível em: https://cidades.ibge.gov.br/xtras/perfil.php?lang $=\& \operatorname{codmun}=120040 \&$ search $=||$ infogr $\%$ E1 ficos:informa $\% \mathrm{E} 7 \% \mathrm{~F} 5$ es-completas

3. Alves DB, Barbosa MTS. Desigualdades na mortalidade por doenças crônicas entre idosos e sua associação com indicadores socioeconômicos no Brasil. Rev Bras Ciênc Env Hum. 2010;7(1):22-33.

4. Lozano R, Naghavi M, Foreman K, Lim S, Shibuya $\mathrm{K}$, Aboyans V, et al. Global and regional mortality from 235 causes of death for 20 age groups in 1990 and 2010: a systematic analysis for the Global Burden of Disease Study 2010. Lancet [Internet]. 2012 [acesso em 10 jan. 2018];380(9859):2095-2128. Disponível em: https://www.ncbi.nlm.nih.gov/pubmed/23245604.

5. Instituto Brasileiro de Geografia e Estatística. Um panorama da saúde no Brasil: acesso e utilização dos serviços, condições de saúde e fatores de risco e proteção à saúde 2008. Rio de Janeiro: IBGE; 2010.

6. Portal da Saúde. DATASUS [Internet]. Brasília, DF: Ministério da Saúde; 2015. Sistema de Informação de mortalidade; 2015 [acesso em 20 jan. 2018]. Disponível em: http://www2.datasus.gov.br/ DATASUS/index.php?area $=0205 \& \mathrm{id}=6937$

7. Doll R, Payne P, Waterhouse JAH. Cancer incidence in five continents. Geneva: Union Internationale Contre le Cancer; 1966. and to evaluate whether, over time, the primary and secondary prevention of CSD and/or improvement of the socioeconomic conditions of the population were more effective. In addition, the results indicate that the overall mortality of the elderly exhibits a declining trend in Rio Branco. The volume and proportion of older people in this region may therefore increase, leading to a need for investment to ensure longevity accompanied by quality of life.

8. Mathers CD, Bernard C, Iburg KM, Inoue M, Fat DM, Shibuya K, et al. Global burden of disease in 2002: data sources, methods and results [Internet]. Geneva: WHO; 2003 [acesso em 14 Jan. 2018]. Disponível em: http://www.who.int/healthinfo/paper54.pdf .

9. França E, Teixeira R, Ishitani L, Duncan BB, CortezEscalante JJ, De Morais OL, et al. Ill-Defined causes of death in Brazil: a redistribution method based on the investigation of such causes. Rev Saúde Pública. 2014;48(4):671-81.

10. Joinpoint Regression Program [Internet]. Bethesda: National Cancer Institute; 2017. Statistical Research and Applications Branch; 2017 [acesso em 12 fev. 2016]. Disponível em: https://surveillance.cancer. gov/branches/srab/

11. Mathias TAF, Jorge MHPM, Laurenti R, Aidar T. Considerações sobre a qualidade de informações de mortalidade na população idosa residente no município de Maringá, Estado do Paraná, Brasil, no período de 1970 a 1998. Epidemiol Serv Saúde. 2005;14(3):159-69.

12. Silva VL, Albuquerque MFPM, Cesse EAP, Luna CF. Perfil de mortalidade do idoso: análise da evolução temporal em uma capital do Nordeste brasileiro de 1996 a 2007. Rev Bras Geriatr Gerontol [Internet]. 2012 [acesso em 11 jan. 2018];14(3):433-41. Disponível em: http://www.scielo.br/scielo.php?script=sci_arttex t\&pid=S1809-98232012000300005

13. Nikolich-Žugich J, Goldman DP, Cohen PR, Cortese D, Fontana L, Kennedy BK, et al. Preparing for an aging world: engaging biogerontologists, geriatricians, and the Society. J Gerontol Ser A Biol Sci Med Sci [Internet]. 2016 [acesso em 04 jan. 2018];71(4):435-44. Disponível em: https://www.ncbi.nlm.nih.gov/pubmed/26419976

14. Alberts SC, Archie EA, Gesquiere LR, Altmann J, Vaupel JW, Christensen K. The Male-Female HealthSurvival Paradox: a comparative perspective on sex differences in aging and mortality. In: Weinstein M, Lane MA. Sociality, Hierarchy, Health: comparative biodemography: a Collection of Papers. Washington: National Academy Press; 2014. p. 339-63. 
15. Terry DF, Nolan VG, Andersen SL, Perls TT, Cawthon R. Association of Longer Telomeres With Better Health in Centenarians. J Gerontol Ser A Biol Sci Med Sci. 2008;63(8):809-12.

16. Gems D. Evolution of sexually dimorphic longevity in humans. Aging [Internet]. 2014 [acesso em 04 jan. 2018];6(2):84-91. Disponível em: https://www.ncbi. nlm.nih.gov/pmc/articles/PMC3969277/

17. Sun F, Sebastiani P, Schupf N, Bae H, Andersen SL, McIntosh A, et al. Extended maternal age at birth of last child and women's longevity in the long life family Study. Menopause. 2016;22(1):26-31.

18. Malta DC, Bernal RTI, Lima MG, Araújo SSC, Silva MMA, Freitas MIF, et al. Doenças crônicas não transmissíveis e a utilização de serviços de saúde: análise da Pesquisa Nacional de Saúde no Brasil. Rev Saúde Pública [Internet]. 2017 [acesso em 04 fev. 2018];51(Supl 1):1-10. Disponível em: http://www.scielo.br/pdf/rsp/ v51s1/pt_0034-8910-rsp-S1518-87872017051000090.pdf

19. Oliveira TC, Medeiros WR, Lima KC. Diferenciais de mortalidade por causas nas faixas etárias limítrofes de idosos. Rev Bras Geriatr Gerontol. 2015;18(1):85-94.

20. Telarolli Júnior R, Loffredo LCM. Mortality of the elderly in a municipality of southeastern Brazil from 2006 to 2011. Ciênc Saúde Coletiva [Internet]. 2014 [acesso em 04 fev. 2018];19(3):975-84. Disponível em: http://www.scielo.br/scielo.php?script=sci_arttext\&p id $=$ S1413-81232014000300975

21. Miranda GMD, Mendes ACG, Silva ALA. O envelhecimento populacional brasileiro: desafios e consequências sociais atuais e futuras. Rev Bras Geriatr Gerontol [Internet]. 2016 [acesso em 10 jan. 2018];19(3):507-19. Disponível em: http://www.scielo.br/ pdf/rbgg/v19n3/pt_1809-9823-rbgg-19-03-00507.pdf

22. Carmo CN, Hacon SS, Jacobson LSV, Mourão DS, Ignotti E. Mortality due to cardiorespiratory diseases in elderly people in Mato Grosso state, 1986 to 2006. Rev Saúde Pública. 2010;44(6):1112-9.

23. Da Rosa LHT, Rossato DD, Bombardelli CL, Sturmer G, Da Rosa PV. Estudo da mortalidade em população idosa de municípios do Rio Grande do Sul no período de 1996 a 2004. Rev Bras Geriatr Gerontol. 2010;13(1):111-9.

24. Garritano CR, Luz PM, Pires MLE, Barbosa MTS, Batista KM. Análise da tendência da mortalidade por acidente vascular cerebral no Brasil no século XXI. Arq Bras Cardiol [Internet]. 2012 [acesso em 28 jan. 2018];98(6):519-27. Disponível em: http://www.scielo.br/scielo.php?pid=S0066782X2012000600007\&script $=$ sci_abstract\&tlng=pt
25. Piuvezam G, Medeiros WR, Costa AV, Emerenciano FF, Santos RC, Seabra DS. Mortalidade em idosos por doenças cardiovasculares: análise comparativa de dois quinquênios. Arq Bras Cardiol [Internet]. 2015 [acesso em 10 fev. 2018]. Disponível em: http://www.scielo.br/ pdf/abc/2015nahead/pt_0066-782X-abc-20150096.pdf

26. Gaui EN, Klein CH, Oliveira GMM. Mortalidade proporcional por insuficiência cardíaca e doenças isquêmicas do coração nas regiões do Brasil de 2004 a 2011. Arq Bras Cardiol. 2016;107(3):230-8.

27. Mansur AP, Favarato D. Mortalidade por doenças cardiovasculares no Brasil e na região metropolitana de São Paulo: atualização 2011. Arq Bras Cardiol. 2012;99(2):755-61.

28. Nichols M, Townsend N, Scarborough P, Rayner $\mathrm{M}$. Trends in age-specific coronary heart disease mortality in the European Union over three decades: 1980-2009. Eur Heart J [Internet]. 2013 [acesso em 10 nov. 2017];34(39):3017-27. Disponível em: https:// www.ncbi.nlm.nih.gov/pubmed/23801825

29. Bezerra PCL. Morbidade autorreferida e percepção de saúde em adultos: inquérito populacional em Rio Branco, AC. 2010 [Dissertação]. Rio Branco: Universidade Federal do Acre; 2010.

30. Reis CS, Noronha K, Wajnman S. Envelhecimento populacional e gastos com internação do SUS: uma análise realizada para o Brasil entre 2000 e 2010. Rev Bras Estud Popul [Internet]. 2016 [acesso em 20 dez. 2017];33(3):591612. Disponível em: http://www.scielo.br/pdf/rbepop/ v33n3/0102-3098-rbepop-33-03-00591.pdf.

31. Borim FSA, Francisco PMSB, Neri AL. Fatores sociodemográficos e de saúde associados à mortalidade em idosos residentes na comunidade. Rev Saúde Pública [Internet]. 2017 [acesso em 08 jan. 2018];51(42):1-12. Disponível em: http://www.scielo.br/pdf/rsp/v51/ pt_0034-8910-rsp-S1518-87872017051006708.pdf

32. Portal da Saúde. DATASUS [Internet]. Brasília, DF: 2013. Sistemas de Informação sobre Mortalidade: consolidação da base de dados de 2011; 2013 [acesso em 20 dez. 2017]. Disponível em : http://tabnet. datasus.gov.br/cgi/sim/Consolida_Sim_2011.pdf

33. Paes NA. Avaliação das estatísticas vitais para estudos de causa de morte dos adultos para estados e capitais do Brasil, 2000. In: Anais do $14^{\circ}$ Encontro da Associação Brasileira de Estudos Populacionais; 20-24 set. 2004; Caxambú-MG. [sem local]: ABEP; 2006. p. 20-24.

34. Morais RM, Costa AL. Uma avaliação do Sistema de Informações sobre Mortalidade. Saúde Debate. 2017;41(1):101-17. 